\title{
Complete genome of Pseudomonas chlororaphis strain UFB2, a soil bacterium with antibacterial activity against bacterial canker pathogen of tomato
}

\author{
Peng Deng ${ }^{1}$, Xiaoqiang Wang ${ }^{1,2}$, Sonya M. Baird ${ }^{1}$ and Shi-En Lu ${ }^{1 *}$
}

\begin{abstract}
Strain UFB2 was isolated from a soybean field soil in Mississippi and identified as a member of Pseudomonas chlororaphis. Strain UFB2 has a broad-spectrum antimicrobial activity against common soil-borne pathogens. Plate assays showed that strain UFB2 was especially efficient in inhibiting the growth of Clavibacter michiganensis 1-07, the causal agent of the devastating bacterial canker of tomato. Here, the complete genome sequence of $P$. chlororaphis strain UFB2 is reported and described. The strain UFB2 genome consists of a circular chromosome of 6,360,256 bp of which $87.86 \%$ are protein-coding bases. Genome analysis revealed multiple gene islands encoding various secondary metabolites such as 2,4-diacetylphloroglucinol. Further genome analysis will provide more details about strain UFB2 antibacterial activities mechanisms and the use of this strain as a potential biocontrol agent.
\end{abstract}

Keywords: Pseudomonas chlororaphis strain UFB2, Complete genome, Biocontrol, Bacterial canker of tomato, Secondary metabolites

\section{Introduction}

Bacterial strains of Pseudomonas chlororaphis are aerobic Gram-positive bacteria and many of the strains possess a wide-spectrum antifungal activity against soil-borne plant pathogens [1-5]. P. chlororaphis strains have been reported to be efficient plant-growth-promoting bacteria, which can be used as inoculants for biofertilization, phytostimulation and biocontrol [6]. The use of $P$. chlororaphis strains as biocontrol agents is promising because they are capable of producing a variety of antimicrobial secondary metabolites including phenazine-1-carboxamide, 2-hydroxyphenazine, pyrrolnitrin, hydrogen cyanide, chitinases and proteases [68]. Moreover, $P$. chlororaphis is considered to be nonpathogenic to humans, wildlife, or the environment according to U.S. environmental protection agency (EPA) [9]. Antimicrobial activities and low risks to animals and the environments have made the bacterium $P$. chlororaphis highly potential biocontrol agents in agriculture $[8,10]$. A genome-wide

\footnotetext{
* Correspondence: sl332@msstate.edu

'Department of Biochemistry, Molecular Biology, Entomology and Plant

Pathology, Mississippi State University, Mississippi State, USA

Full list of author information is available at the end of the article
}

research and analysis could provide useful information about the mechanisms of how $P$. chlororaphis protects plants against soil-borne phytopathogens. Currently, the whole genomes of a few $P$. chlororaphis strains that exhibit antifungal activity have been sequenced. These include $P$. chlororaphis strain PA23 that can protect canola from stem rot disease caused by the fungal pathogen Sclerotinia sclerotiorum $[2,11]$, and P. chlororaphis PCL1606 that was isolated from avocado rhizosphere and exhibited biocontrol activity against soil-borne phytopathogenic fungi [1]. In addition, another functionally-uncharacterized strain, $P$. chlororaphis subsp. aurantiaca JD37, was recently sequenced (NCBI reference sequence: NZ_CP009290.1). Genome sequences of $P$. chlororaphis strains with significant antibacterial activity have not been reported previously.

Strain UFB2 was isolated from a soybean field soil in Mississippi. Preliminary analysis of the 16S rRNA gene indicated that it is a member of $P$. chlororaphis. Plate assays indicated $P$. chlororaphis strain UFB2 has a broad spectrum of antimicrobial activities, especially against bacterial canker pathogen of tomato: Clavibacter michiganensis [12, 13]. Greenhouse trials demonstrated both living cells and 


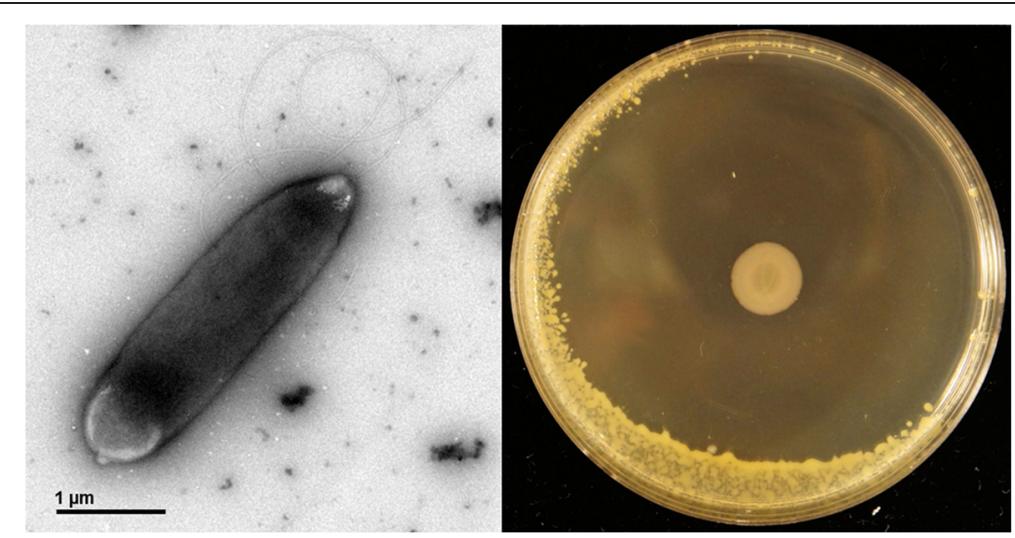

Fig. 1 Image of $P$. chlororaphis UFB2 cells and plate assay of UFB2 antibacterial activity against Clavibacter michiganensis 1-07. The plate bioassay was conducted as described by Scholz-Schroeder and colleagues [44]

Table 1 Classification and general features of Pseudomonas chlororaphis UFB2 according to the MIGS recommendations [55]

\begin{tabular}{|c|c|c|c|}
\hline MIGS ID & Property & Term & Evidence code $^{a}$ \\
\hline & Classification & Domain Bacteria & TAS [56] \\
\hline & & Phylum Proteobacteria & TAS [57] \\
\hline & & Class Gammaproteobacteria & $\operatorname{TAS}[58,59]$ \\
\hline & & Order Pseudomonadales & $\operatorname{TAS}[19,60]$ \\
\hline & & Family Pseudomonadaceae & $\operatorname{TAS}[19,61]$ \\
\hline & & Genus Pseudomonas & $\operatorname{TAS}[19,61-63]$ \\
\hline & & Species Pseudomonas chlororaphis & $\operatorname{TAS}[19,64,65]$ \\
\hline & & strain: UFB2 & NAS \\
\hline & Gram stain & negative & TAS [66] \\
\hline & Cell shape & Rod & TAS [66] \\
\hline & Motility & Motile & TAS [66] \\
\hline & Sporulation & None & NAS \\
\hline & Temperature range & Mesophilic & IDA \\
\hline & Optimum temperature & $33^{\circ} \mathrm{C}$ & IDA \\
\hline & pH range; Optimum & not determined & IDA \\
\hline & Carbon source & $\begin{array}{l}\text { D-glucose, D-galactose, L-rhamnose, D-mannitol, D-raffinose, } \\
\text { D-fructose, D-arabinose, 2D-ribose, L-arabinose, L-xylose, D-xylose. }\end{array}$ & TAS [66] \\
\hline MIGS-6 & Habitat & Soil & NAS \\
\hline MIGS-6.3 & Salinity & not determined & IDA \\
\hline MIGS-22 & Oxygen requirement & Aerobic & NAS \\
\hline MIGS-15 & Biotic relationship & free-living/Rhizospheric & NAS \\
\hline MIGS-14 & Pathogenicity & non-pathogen & IDA \\
\hline MIGS-4 & Geographic location & Mississippi, USA & IDA \\
\hline MIGS-5 & Sample collection & 2011 & IDA \\
\hline MIGS-4.1 & Latitude & $34.1 \mathrm{~N}$ & IDA \\
\hline MIGS-4.2 & Longitude & $90.6 \mathrm{~W}$ & IDA \\
\hline MIGS-4.4 & Altitude & $40 \mathrm{M}$ & IDA \\
\hline
\end{tabular}

${ }^{a}$ Evidence codes - IDA Inferred from Direct Assay, TAS Traceable Author Statement (i.e., a direct report exists in the literature), NAS Non-traceable Author Statement (i.e., not directly observed for the living, isolated sample, but based on a generally accepted property for the species, or anecdotal evidence). These evidence codes are from the Gene Ontology project [67] 
culture extract of strain UFB2 can be used for disease management of bacterial canker of tomato. In this study, the $P$. chlororaphis strain UFB2 complete genome sequence and annotation are reported. The gene islands within strain UFB2 genome that encode various secondary metabolites, including antimicrobial compounds, are also described. The detailed description of the strain UFB2 genome will shed light into further studies of biocontrol effectiveness and applications of Pseudomonas species.

\section{Organism information}

\section{Classification and features}

Strain UFB2 was isolated from rhizosphere soil sample collected from soybean field near Cleveland, Mississippi, USA, where healthy soybean plants were found growing in charcoal rot disease patch. Phylogenetic analyses based on multilocus sequence typing [14] (gyrB, rpoB, $\mathrm{rpoD}$ and $16 \mathrm{~s}$ rRNA) revealed that strain UFB2 belongs to Pseudomonas chlororaphis (Fig. 2). Strain UFB2 is rod-shaped, motile, non-spore-forming Gram-negative bacterium in the order Pseudomonadales of the class Gammaproteobacteria. UFB2 cells are approximately $3.0 \pm 0.8 \mu \mathrm{m}$ in width and $0.9 \pm 0.3 \mu \mathrm{m}$ in length (Fig. 1). The strain is relatively fast-growing, forming approximately $1 \mathrm{~mm}$ opaque yellowish colonies after overnight incubation at $28{ }^{\circ} \mathrm{C}$ on nutrient-broth yeast extract agar
[15]. Strain UFB2 can also be grown on rich media such as LB [16] and PDA, as well as M9 minimal medium [17]. Phenotypic characterization of strain UFB2 was carried out using the API $50 \mathrm{CH}$ system as recommended by manufacturer. According to the result, strain UFB2 could utilize almost all carbon sources in API $50 \mathrm{CH}$ tests, including D-glucose, D-galactose, L-rhamnose, Dmannitol, D-raffinose, D-fructose, D-arabinose, D-ribose, L-arabinose, L-xylose and D-xylose, but not potassium gluconate.

Plate bioassays demonstrated that strain UFB2 possesses significant antibacterial activity against a broad array of plant bacterial pathogens. Other than Clavibacter michiganensis 1-07, the tested bacteria sensitive to strain UFB2 also include Erwinia amylovora [18, 19], Burkholderia glumae [20], Ralstonia solanacearum Rso [21, 22] and Erwinia carotovora WSCH1 [19, 23]. Of the tested plant pathogenic bacteria, the Gram-positive bacterium Clavibacter michiganensis $1-07$, the pathogen causing bacterial canker of tomato [24], is most sensitive to strain UFB2 with a radius of $28 \pm 1 \mathrm{~mm}$ clear inhibitory zone (Fig. 1). In addition, the growth of fungal pathogen Geotrichum candidum Km, which causes sour rot of citrus fruits, tomatoes, carrot and some vegetables [25], can also be inhibited by strain UFB2. To test the field biocontrol efficacy of strain UFB2, greenhouse

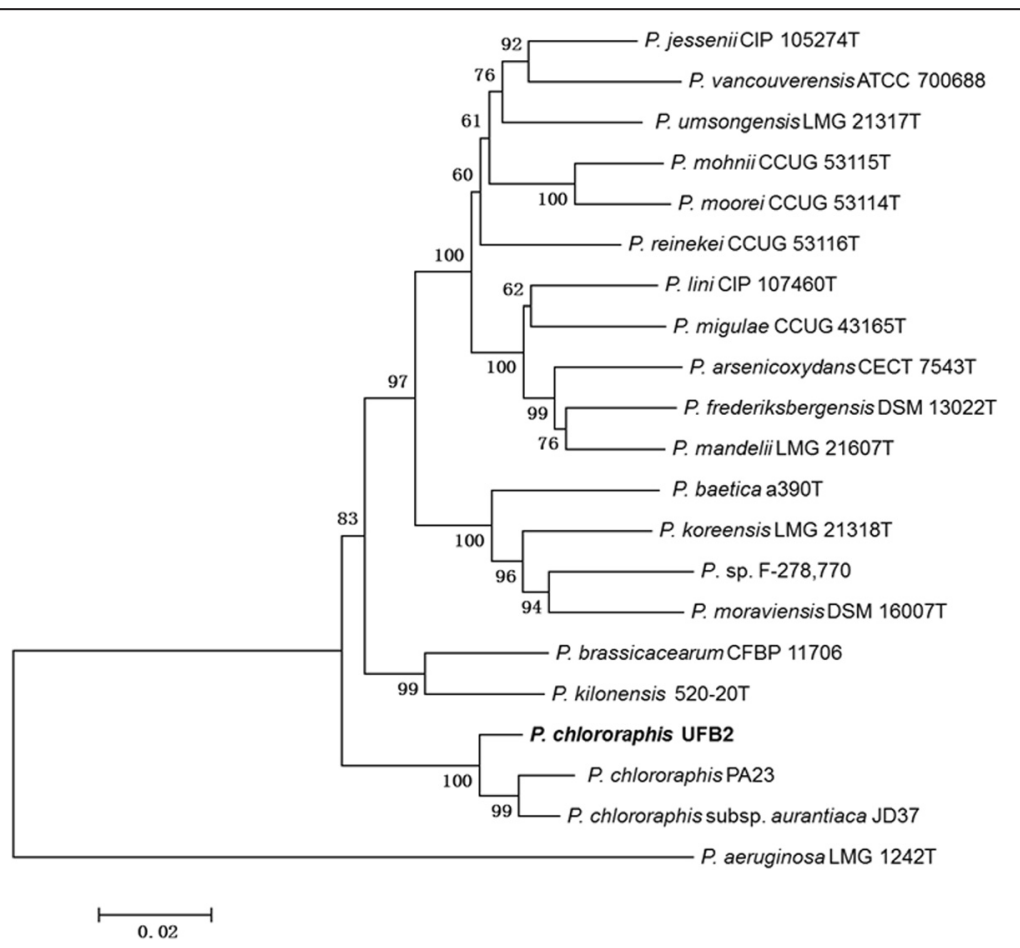

Fig. 2 Phylogenetic analysis of concatenated four multilocus sequence typing loci of $P$. chlororaphis UFB2 and related species. Phylogenetic tree based on the concatenated sequence (3775 bp) of four housekeeping gene fragments [gyrB (729 bp), rpoB (885 bp), rpoD (711 bp) and $16 \mathrm{~s}$ rRNA (1450 bp)]. Phylogenetic analyses were performed using MEGA, version 6.06 [51]. The tree was built using the Neighbor-Joining method [52]. Bootstrap analysis with 1000 replicates was performed to assess the support of the clusters 
Table 2 Project information

\begin{tabular}{lll}
\hline MIGS ID & Property & Term \\
\hline MIGS 31 & Finishing quality & Finished \\
MIGS-28 & Libraries used & libraries of 400 bp, mate pair library of 2,000, 5,000 and 8,000 bp \\
MIGS 29 & Sequencing platforms & Illumina \\
MIGS 31.2 & Fold coverage & $600 \times$ \\
MIGS 30 & Assemblers & DNAStar Seqman NGen v12 \\
MIGS 32 & Gene calling method & NCBI Prokaryotic Genome Annotation Pipeline \\
& Locus Tag & VM99 \\
& Genbank ID & CP011020 \\
& GenBank Date of Release & Jun 9 $9^{\text {th }}, 2015$ \\
& GOLD ID & Gp0111981 \\
& BIOPROJECT & PRJNA277727 \\
MIGS13 & Source Material Identifier & UFB2 \\
& Project relevance & Biocontrol \\
\hline
\end{tabular}

experiments were set up according to the method described by Lu and Ingram [26]. Preliminary data showed the control efficacies of both strain UFB2 culture extract and living cells on bacterial canker of tomato are equivalent to that of streptomycin at the recommended rate for plant disease management. The genome of strain UFB2 was sequenced with the aim to identify the genes associated with the antimicrobial characters. The information about the genome sequence of strain UFB2 is summarized in Table 1, and its phylogenetic position is shown in Fig. 2.

\section{Chemotaxonomic data}

Fatty acid analysis was performed by gas chromatography (gas chromatograph, model 6890 N, Agilent Technologies) and analyzed by the Microbial Identification System (MIDI, Sherlock Version 6.1; database, TSBA40). The analysis of total cells showed the major fatty acids are $C_{16: 1}^{{ }^{\omega 7}{ }^{7} \mathrm{c}}$ (32\%), $\mathrm{C}_{16: 0}(28 \%), \mathrm{C}_{18: 1}{ }^{\omega 7 \mathrm{c}}$ (19\%). Fatty acid 3-hydroxy $\mathrm{C}_{12: 0}(5 \%), \mathrm{C}_{12: 0}(4 \%), 2$-hydroxy $\mathrm{C}_{12: 0}$ (4\%) and 3-hydroxy $C_{10: 0}(3 \%)$ were found in minor amount.

\section{Genome sequencing information Genome project history}

$P$. chlororaphis strain UFB2 was selected for sequencing because of its significant antimicrobial activities and its potential as a biocontrol agent for agricultural use. Genomes of three $P$ chlororaphis strains have been sequenced as of May 2015. Sequencing of the whole genome of strain UFB2 makes more data available for genome comparison and analysis within $P$. chlororaphis species.

The genome project is deposited in the Genomes OnLine Database [27] and the NCBI BioProject database [28]. The annotated genome is publicly available from the Intergrated Microbial Genomes Database [29] under the accession number Gp0111981 and GenBank under accession number CP011020. A summary of the project information is provided in Table 2 .

\section{Growth conditions and genomic DNA preparation}

P. chlororaphis strain UFB2 was cultured in liquid NBY medium overnight at $28{ }^{\circ} \mathrm{C}$ in a shaker at $220 \mathrm{rpm}$. The genomic DNA was extracted from $50 \mathrm{~mL}$ of the culture using the Wizard Genomic DNA Purification Kit (Promega Corporation, Madison, WI, USA). Totally approximately $900 \mu \mathrm{g}$ of DNA were obtained with an OD260/ 280 of 1.9. The DNA sample was used for library

Table 3 Genome statistics

\begin{tabular}{lrc}
\hline Attribute & \multicolumn{1}{c}{ Value } & \% of Total \\
\hline Genome size (bp) & $6,360,256$ & 100.00 \\
DNA coding (bp) & $5,588,126$ & 87.86 \\
DNA G + C (bp) & $3,945,558$ & 62.03 \\
DNA scaffolds & 1 & 100.00 \\
Total genes & 5,556 & 100.00 \\
Protein coding genes & 5,473 & 98.51 \\
RNA genes & 83 & 1.49 \\
Pseudo genes & 90 & 1.62 \\
Genes in internal clusters & 5,473 & 98.51 \\
Genes with function prediction & 4,886 & 87.94 \\
Genes assigned to COGs & 4,092 & 73.65 \\
Genes with Pfam domains & 4,748 & 85.46 \\
Genes with signal peptides & 577 & 10.39 \\
Genes with transmembrane helices & 1,228 & 22.10 \\
CRISPR repeats & 0 & 0 \\
\hline
\end{tabular}


construction with Illumina Genomic DNA Sample Preparation Kit (Illumina, CA, USA).

\section{Genome sequencing and assembly}

One standard library with an average insert size of $400 \mathrm{bp}$ and three mate pair libraries with an average insert size of 2,000 bp, 5,000 bp and 8,000 bp were prepared and sequenced on the Illumina MiSeq instrument according to the manufacturer's instructions. The genome was de novo assembled using a method as described by Durfee et al. [30] using DNAStar Seqman NGen (Version 12, DNASTAR, Inc. Madison, WI U.S.). The standard library and 2,000 bp mate pair library were selected for the de novo assembly. A total of 30 million short reads were scanned and extracted from the raw data files as input data. The short reads were preprocessed by Seqman NGen to trim adaptors and filter lowquality reads. Automatic Mer size and a minimum match percentage of $98 \%$ were selected. 29 million short reads were assembled into 29 contigs and SeqMan Pro (Version 12, DNASTAR, Inc. Madison, WI U.S.) was used to order the contigs in one scaffold according to the mate pair data. The first round assembled sequence was then used as a template for a complete reassembly. The 2,000 bp and 8,000 bp mate pair data were incorporated to proofread the first assembly and to maximize coverage and quality. Adjacent contigs, if possible, were merged. Remaining gaps were filled by PCR and Sanger sequencing. No contigs that might correspond to plasmids remained unassembled. IslandViewer [31] was used to predict and identify genomic islands.

\section{Genome annotation}

Automatic annotation was performed using the NCBI Prokaryotic Genome Annotation Pipeline [32], which combines gene calling algorithm with similarity-based

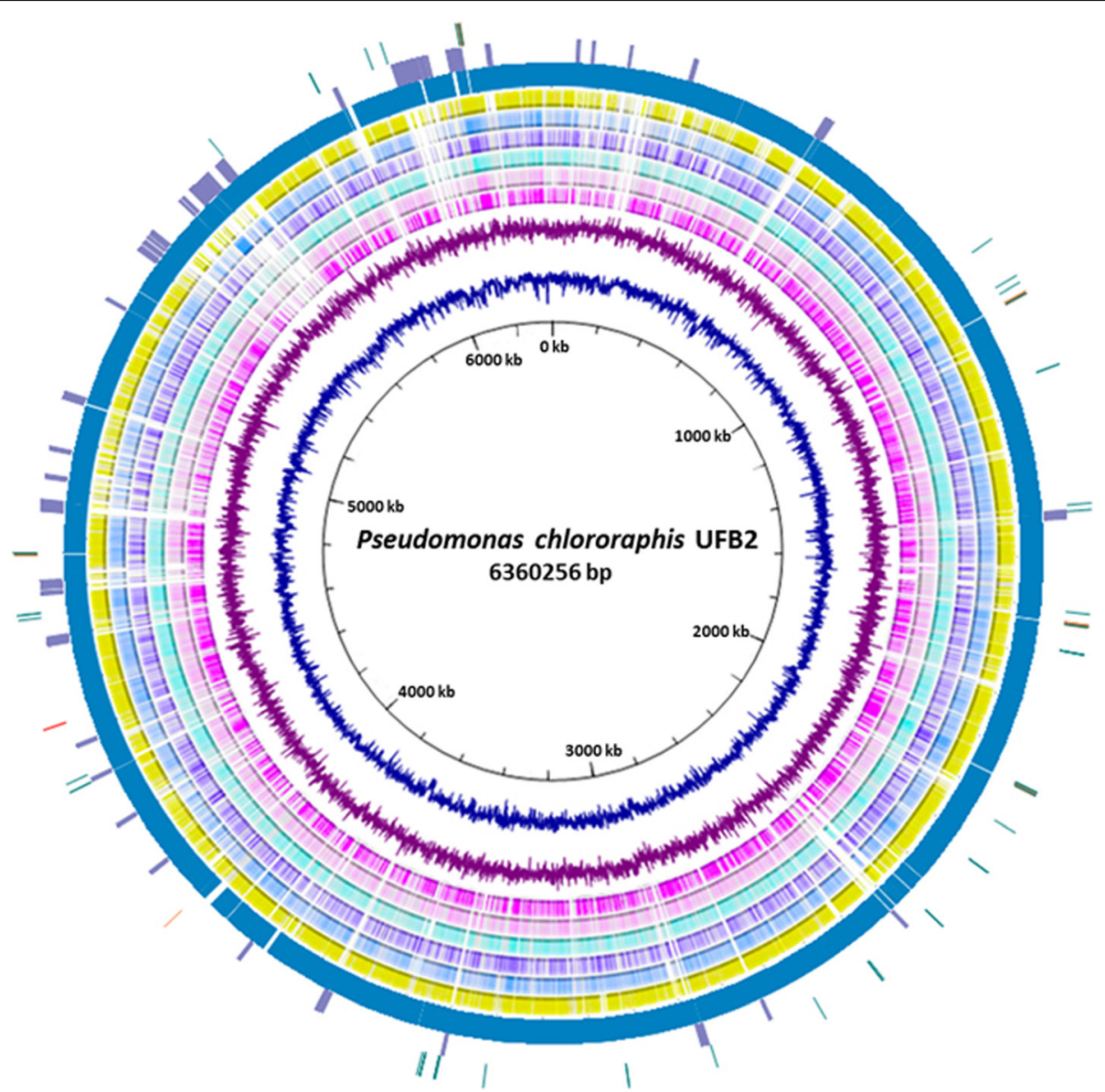

Fig. 3 Circular representation of the $P$. chlororaphis UFB2 genome compared with six sequenced Pseudomonas whole genomes. Rings from inside to outside: (1) Scale, (2) GC content (navy), (3) GC skew (purple), (4) BLAST comparison with P. syringae pv. syringae B728a (deep pink), (5) BLAST comparison with P. putida KT2440 (pink), (6) BLAST comparison with P. chlororaphis strain PA23 (cyan), (7) BLAST comparison with P. aeruginosa PAO1 (violet), (8) BLAST comparison with P. fluorescens Pf0-1 (skyblue), (9) BLAST comparison with P. sp. UW4 (yellow), (10) Coding sequences of P. chlororaphis UFB2 genome (dark cyan), (11) Gene islands (medium purple), (12) rRNA genes (orange), tRNA genes (dark green) and ncRNA (red). BLASTn comparison of genomes was visualized by BRIG [53] and UFB2 genome the image was generated with Circos [54] 
gene detection approach to predict protein-coding genes, structural RNAs (5S, 16S, 23S), tRNAs and small noncoding RNAs. Additional gene prediction analysis and functional annotation were performed by the Integrated Microbial Genomes platform [29].

\section{Genome properties}

The complete genome of $P$. chlororaphis strain UFB2 consists of one circular chromosome of 6,360,256 bp with a GC content of $62.03 \% .5,556$ genes were identified from the genome, of which 5,473 are protein coding genes. 90 of the 5,556 genes were predicted to be pseudogenes or partial genes. The genome encodes 1 noncoding RNA, 5 rRNA operons and 65 tRNAs. Seventy genomic islands ranging from $4 \mathrm{kbp}$ to $43.5 \mathrm{kbp}$ were also identified throughout the strain UFB2 genome, among which majority of the islands encode hypothetical proteins. The genome features of $P$. chlororaphis strain UFB2 are summarized in Tables 3 and 4 , and the circular chromosome of strain UFB2 is shown in Fig. 3.

\section{Insights from the genome sequence}

Blast research of $P$. chlororaphis strain UFB2 genome against $P$. syringae pv. syringae $\mathrm{B} 728 \mathrm{a}$ (NC_007005), $P$. putida KT2440 (NC_002947), P. chlororaphis strain PA23 (NZ_CP008696), P. aeruginosa PAO1 (NC_002516), P. fluorescens PfO-1 (NC_007492) and P. sp. UW4 (NC_019670) genome revealed multiple unique gene regions which were only found in the strain UFB2 genome (Fig. 3). The BLASTn atlas showed noticeable genome diversity of strain UFB2 when compared to other Pseudomonas species. Seventy genomic islands ranging from 4 $\mathrm{kbp}$ to $30 \mathrm{kbp}$ were also identified throughout the strain UFB2 genome, indicating significant horizontal gene transfers occurred during the evolution of strain UFB2 to better adapt the environment it inhabited.

P. chlororaphis strain UFB2 harbors an intact phl gene cluster (VM99_23970-23995), which is responsible for biosynthesis of the antimicrobial compound 2,4-diacetylphloroglucinol [33, 34]. 2,4-diacetylphloroglucinol is an especially efficient agent against soil borne fungal plant pathogens [35]. The phl gene cluster is involved in the Pseudomonas antifungal activity against Clavibacter

Table 4 Number of genes associated with general COG functional categories

\begin{tabular}{|c|c|c|c|}
\hline Code & Value & $\%$ age & Description \\
\hline J & 231 & 4.89 & Translation, ribosomal structure and biogenesis \\
\hline A & 1 & 0.02 & RNA processing and modification \\
\hline K & 418 & 8.85 & Transcription \\
\hline L & 123 & 2.60 & Replication, recombination and repair \\
\hline B & 3 & 0.06 & Chromatin structure and dynamics \\
\hline $\mathrm{D}$ & 39 & 0.83 & Cell cycle control, Cell division, chromosome partitioning \\
\hline V & 101 & 2.14 & Defense mechanisms \\
\hline $\mathrm{T}$ & 316 & 6.69 & Signal transduction mechanisms \\
\hline M & 262 & 5.55 & Cell wall/membrane biogenesis \\
\hline $\mathrm{N}$ & 166 & 3.52 & Cell motility \\
\hline W & 44 & 0.93 & Extracellular structures \\
\hline$U$ & 137 & 2.90 & Intracellular trafficking and secretion \\
\hline $\mathrm{O}$ & 166 & 3.52 & Posttranslational modification, protein turnover, chaperones \\
\hline C & 304 & 6.44 & Energy production and conversion \\
\hline G & 227 & 4.81 & Carbohydrate transport and metabolism \\
\hline E & 483 & 10.23 & Amino acid transport and metabolism \\
\hline $\mathrm{F}$ & 92 & 1.95 & Nucleotide transport and metabolism \\
\hline $\mathrm{H}$ & 242 & 5.12 & Coenzyme transport and metabolism \\
\hline । & 234 & 4.96 & Lipid transport and metabolism \\
\hline$P$ & 257 & 5.44 & Inorganic ion transport and metabolism \\
\hline Q & 142 & 3.01 & Secondary metabolites biosynthesis, transport and catabolism \\
\hline $\mathrm{R}$ & 430 & 9.11 & General function prediction only \\
\hline S & 260 & 5.51 & Function unknown \\
\hline- & 1464 & 26.35 & Not in COGs \\
\hline
\end{tabular}


michiganensis 1-07 [36]. Hydrogen cyanide [37, 38] biosynthesis gene homologs were also identified in strain UFB2 genome. The production of hydrogen cyanide by Pseudomonas species helps protect plants from soil-borne fungal pathogens $[39,40]$. Biosynthetic gene clusters of common Pseudomonas species-produced antibiotics such as phenazine [41], pyrrolnitrin [42] and pyoluteorin [43] were not identified in strain UFB2 genome. Biosynthetic gene clusters of common toxins that contribute to plant and animal pathogenicity and/or virulence of Pseudomonas species were also searched for within strain UFB2 genome. The toxin biosynthetic gene cluster that were not identified in strain UFB2 genome include the phytotoxin lipopeptide syringomycin [44], tobacco wildfire spotting causal agent tabtoxin [45], bacterial canker of kiwifruit causal agent phaseolotoxin [46], plant-hormone-mimic toxin coronatine [47], and cytotoxic agent pederin [48]. Strain UFB2 genome harbors homolog genes to those in the bacterial apical necrosis causal agent mangotoxin [49] biosynthesis gene cluster. However, $m b o C$ gene homolog that is required for mangotoxin production [50] was not identified in strain UFB2 genome. Overall, the lack of the key pathogenicity/virulence genes in strain UFB2 further indicates that strain UFB2 has a great potential as a biocontrol agent.

\section{Conclusions}

The complete genome sequence of $P$. chlororaphis strain UFB2 is described in this report. The strain UFB2 was originally isolated from the rhizosphere of a healthy soybean plant growing in a group of plants exhibiting charcoal rot disease in Mississippi. This strain possesses significant antimicrobial activities against a wide range of plant pathogenic bacteria and fungi. It is evident that the genome of $P$. chlororaphis strain UFB2 harbors the complete gene set for production of the antimicrobial compounds 2,4-DAPG and $\mathrm{HCN}$, which may largely contribute to its antimicrobial activities. However, gene homologs required for biosynthesis of all the known toxins to plants, such as syringomycin, tabtoxin, phaseolotoxin, tolaasin, coronatine, or pederin, were absent from the strain UFB2 genome. The genome sequence of P. chlororaphis strain UFB2 will help in understanding genetic mechanisms of the antimicrobial activity studies that are useful for development of biologically-based disease management in agriculture.

\section{Competing interests}

The authors declare no competing interests.

\section{Authors' contributions}

PD and SL designed the experiments; PD, XW, and SB performed the experiments; PD and SL wrote the manuscript and all authors read, critiqued and edited the manuscript.

\section{Acknowledgements}

We thank Chuan-Yu Hsu and Kurt C. Showmaker for sequencing services and Richard Baird, Sead Sabanadzovic and Justin Thornton for helpful discussion. This research was funded by USDA NIFA to SL (MIS-401170).

\section{Author details}

${ }^{1}$ Department of Biochemistry, Molecular Biology, Entomology and Plant Pathology, Mississippi State University, Mississippi State, USA. ${ }^{2}$ Department of Plant Pathology, Shandong Agricultural University, Taian 271018Shandong, China.

Received: 19 June 2015 Accepted: 29 September 2015

Published online: 01 December 2015

\section{References}

1. Calderon CE, Ramos C, de Vicente A, Cazorla FM. Comparative genomic analysis of Pseudomonas chlororaphis PCL1606 reveals new insight into antifungal compounds involved in biocontrol. Mol Plant Microbe Interact. 2015;28(3):249-60.

2. Loewen PC, Villenueva J, Fernando WG, de Kievit T. Genome Sequence of Pseudomonas chlororaphis Strain PA23. Genome Announc 2014; 2(4), doi: 10.1128/genomeA.00689-14.

3. Loper JE, Hassan KA, Mavrodi DV, Davis 2nd EW, Lim CK, Shaffer BT, et al. Comparative genomics of plant-associated Pseudomonas spp: insights into diversity and inheritance of traits involved in multitrophic interactions. PLoS Genet. 2012;8(7):e1002784.

4. Shen $\mathrm{X}$, Chen $\mathrm{M}, \mathrm{Hu} \mathrm{H}$, Wang $\mathrm{W}$, Peng $\mathrm{H}, \mathrm{Xu}$ P, et al. Genome sequence of Pseudomonas chlororaphis GP72, a root-colonizing biocontrol strain. J Bacteriol. 2012;194(5):1269-70.

5. Kim MS, Kim YC, Cho BH. Gene expression analysis in cucumber leaves primed by root colonization with Pseudomonas chlororaphis $\mathrm{O}$ upon challengeinoculation with Corynespora cassiicola. Plant Biol (Stuttg). 2004;6(2):105-8.

6. Bloemberg GV, Lugtenberg BJ. Molecular basis of plant growth promotion and biocontrol by rhizobacteria. Curr Opin Plant Biol. 2001;4(4):343-50.

7. Chin AWTF, Bloemberg GV, Mulders IH, Dekkers LC, Lugtenberg BJ. Root colonization by phenazine-1-carboxamide-producing bacterium Pseudomonas chlororaphis PCL1391 is essential for biocontrol of tomato foot and root rot. Mol Plant Microbe Interact. 2000;13(12):1340-5.

8. Selin C, Habibian R, Poritsanos N, Athukorala SN, Fernando D, de Kievit TR. Phenazines are not essential for Pseudomonas chlororaphis PA23 biocontrol of Sclerotinia sclerotiorum, but do play a role in biofilm formation. FEMS Microbiol Ecol. 2010;71(1):73-83.

9. Pseudomonas chlororaphis strain 63-28 (006478) Fact Sheet [http://www. epa.gov/opp00001/chem_search/reg_actions/registration/fs_PC-006478_01Apr-01.pdf]

10. Tombolini R, van der Gaag DJ, Gerhardson B, Jansson JK. Colonization pattern of the biocontrol strain Pseudomonas chlororaphis MA 342 on barley seeds visualized by using green fluorescent protein. Appl Environ Microbiol. 1999;65(8):3674-80.

11. Savchuk S, Dilantha Fernando WG. Effect of timing of application and population dynamics on the degree of biological control of Sclerotinia sclerotiorum by bacterial antagonists. FEMS Microbiol Ecol. 2004;49(3):379-88.

12. Eichenlaub R, Gartemann KH. The Clavibacter michiganensis subspecies: molecular investigation of gram-positive bacterial plant pathogens. Annu Rev Phytopathol. 2011;49:445-64.

13. Davis MJ, Gillaspie AG, Vidaver AK, Harris RW. Clavibacter: a new genus containing some phytopathogenic coryneform bacteria, including Clavibacter xyli subsp. xyli sp. nov., subsp. nov. and Clavibacter xyli subsp. cynodontis subsp. nov., pathogens that cause ratoon stunting disease of sugarcane and bermudagrass stunting disease. Int J Syst Bacteriol. 1984;34:107-17.

14. Maiden MC. Multilocus sequence typing of bacteria. Annu Rev Microbiol. 2006;60:561-88

15. Vidaver AK. Synthetic and complex media for the rapid detection of fluorescence of phytopathogenic pseudomonads: effect of the carbon source. Appl Microbiol. 1967;15(6):1523-4.

16. Bertani G. Studies on lysogenesis. I. The mode of phage liberation by lysogenic Escherichia coli. J Bacteriol. 1951;62(3):293-300.

17. Wang CH, Koch AL. Constancy of growth on simple and complex media. J Bacteriol. 1978;136(3):969-75.

18. Winslow CE, Broadhurst J, Buchanan RE, Krumwiede C, Rogers LA, Smith GH. The families and genera of the bacteria: final report of the committee of 
the society of american bacteriologists on characterization and classification of bacterial types. J Bacteriol. 1920;5(3):191-229.

19. Skerman VBD, McGowan V, Sneath PHA. Approved lists of bacterial names. Int J Syst Bacteriol. 1980;30:225-420.

20. Urakami T, Ito-Yoshida C, Araki H, Kijima T, Suzuki Kl, Komagata K. Transfer of Pseudomonas plantarii and Pseudomonas glumae to Burkholderia as Burkholderia spp. and description of Burkholderia vandii sp. nov. Int J Syst Bacteriol. 1994:44:235-45.

21. Yabuuchi E, Kosako Y, Yano I, Hotta H, Nishiuchi Y. Transfer of two Burkholderia and an Alcaligenes species to Ralstonia gen. Nov:: Proposal of Ralstonia pickettii (Ralston, Palleroni and Doudoroff 1973) comb. Nov., Ralstonia solanacearum (Smith 1896) comb. Nov. and Rals tonia eutropha (Davis 1969) comb. Nov. Microbiol Immunol. 1995;39(11):897-904.

22. Validation of the publication of new names and new combinations previously effectively published outside the IJSB. Int I Syst Bacteriol. 1996;46(2):625-626.

23. Waldee EL. Comparative studies of some peritrichous phytopathogenic bacteria; 1945.

24. Gartemann KH, Kirchner O, Engemann J, Grafen I, Eichenlaub R, Burger A. Clavibacter michiganensis subsp. michiganensis: first steps in the understanding of virulence of a Gram-positive phytopathogenic bacterium. J Biotechnol. 2003;106(2-3):179-91.

25. Thornton CR, Slaughter DC, Davis RM. Detection of the sour-rot pathogen Geotrichum candidum in tomato fruit and juice by using a highly specific monoclonal antibody-based ELISA. Int J Food Microbiol. 2010;143(3):166-72.

26. Ingram DM, Lu S-E. Evaluation of Foliar Sprays of Bacteriophages for the Management of Bacterial Canker in Greenhouse Tomatoes. [http://www. plantmanagementnetwork.org/pub/php/research/2009/tomato/].

27. Pagani I, Liolios K, Jansson J, Chen IM, Smirnova T, Nosrat B, et al. The Genomes OnLine Database (GOLD) v.4: status of genomic and metagenomic projects and their associated metadata. Nucleic Acids Res. 2012:40:D571-9.

28. Barrett T, Clark K, Gevorgyan R, Gorelenkov V, Gribov E, Karsch-Mizrachi I, et al. BioProject and BioSample databases at NCBI: facilitating capture and organization of metadata. Nucleic Acids Res. 2012;40(Database issue):D57-63.

29. Chen IM, Palaniappan K, Chu K, Szeto E, Grechkin Y, Ratner A, et al. IMG: the Integrated Microbial Genomes database and comparative analysis system. Nucleic Acids Res. 2012;40:D115-22.

30. Durfee T, Nelson R, Baldwin S, Plunkett 3rd G, Burland V, Mau B, et al. The complete genome sequence of Escherichia coli DH10B: insights into the biology of a laboratory workhorse. J Bacteriol. 2008;190(7):2597-606.

31. Langille MG, Brinkman FS. IslandViewer: an integrated interface for computational identification and visualization of genomic islands. Bioinformatics. 2009;25(5):664-5.

32. Tatiana T, Mike D, Azat B, Vyacheslav C, Stacy C, Wenjun L. Prokaryotic Genome Annotation Pipeline. The NCBI Handbook [Internet]. 2nd edition. 2013.

33. Bangera MG, Thomashow LS. Identification and characterization of a gene cluster for synthesis of the polyketide antibiotic 2,4-diacetylphloroglucinol from Pseudomonas fluorescens Q2-87. J Bacteriol. 1999;181(10):3155-63.

34. Cronin D, Moenne-Loccoz Y, Fenton A, Dunne C, Dowling DN, O'Gara F. Role of 2,4-Diacetylphloroglucinol in the Interactions of the Biocontrol Pseudomonad Strain F113 with the Potato Cyst Nematode Globodera rostochiensis. Appl Environ Microbiol. 1997;63(4):1357-61.

35. Shanahan P, O'Sullivan DJ, Simpson P, Glennon JD, O'Gara F. Isolation of 2,4-diacetylphloroglucinol from a fluorescent pseudomonad and investigation of physiological parameters influencing its production. Appl Environ Microbiol. 1992;58(1):353-8.

36. Lanteigne C, Gadkar VJ, Wallon T, Novinscak A, Filion M. Production of DAPG and HCN by Pseudomonas sp. LBUM300 contributes to the biological control of bacterial canker of tomato. Phytopathology. 2012;102(10):967-73.

37. Laville J, Blumer C, Von Schroetter C, Gaia V, Defago G, Keel C, et al. Characterization of the $\mathrm{h} \cap \mathrm{ABC}$ gene cluster encoding hydrogen cyanide synthase and anaerobic regulation by ANR in the strictly aerobic biocontrol agent Pseudomonas fluorescens CHAO. J Bacteriol. 1998;180(12):3187-96.

38. Gross H, Loper JE. Genomics of secondary metabolite production by Pseudomonas spp. Nat Prod Rep. 2009;26(11):1408-46.

39. Voisard C, Keel C, Haas D, Defago G. Cyanide production by Pseudomonas fluorescens helps suppress black root rot of tobacco under gnotobiotic conditions. EMBO J. 1989;8(2):351-8.

40. Haas D, Blumer C, Keel C. Biocontrol ability of fluorescent pseudomonads genetically dissected: importance of positive feedback regulation. Curr Opin Biotechnol. 2000;11(3):290-7.
41. Mavrodi DV, Bonsall RF, Delaney SM, Soule MJ, Phillips G, Thomashow LS. Functional analysis of genes for biosynthesis of pyocyanin and phenazine-1carboxamide from Pseudomonas aeruginosa PAO1.J Bacteriol. 2001;183(21):6454-65.

42. Costa R, van Aarle IM, Mendes R, van Elsas JD. Genomics of pyrrolnitrin biosynthetic loci: evidence for conservation and whole-operon mobility within gram-negative bacteria. Environ Microbiol. 2009;1 1(1):159-75.

43. Souza JT, Raaijmakers JM. Polymorphisms within the prnD and pltC genes from pyrrolnitrin and pyoluteorin-producing Pseudomonas and Burkholderia spp. FEMS Microbiol Ecol. 2003:43(1):21-34.

44. Scholz-Schroeder BK, Hutchison ML, Grgurina I, Gross DC. The contribution of syringopeptin and syringomycin to virulence of Pseudomonas syringae pv. syringae strain B301D on the basis of sypA and syrB1 biosynthesis mutant analysis. Mol Plant Microbe Interact. 2001;14(3):336-48.

45. Kinscherf TG, Coleman RH, Barta TM, Willis DK. Cloning and expression of the tabtoxin biosynthetic region from Pseudomonas syringae. J Bacteriol. 1991;173(13):4124-32.

46. Hwang MS, Morgan RL, Sarkar SF, Wang PW, Guttman DS. Phylogenetic characterization of virulence and resistance phenotypes of Pseudomonas syringae. Appl Environ Microbiol. 2005;71(9):5182-91.

47. Zheng XY, Spivey NW, Zeng W, Liu PP, Fu ZQ, Klessig DF, et al. Coronatine promotes Pseudomonas syringae virulence in plants by activating a signaling cascade that inhibits salicylic acid accumulation. Cell Host Microbe. 2012;11(6):587-96.

48. Piel J, Hofer I, Hui D. Evidence for a symbiosis island involved in horizontal acquisition of pederin biosynthetic capabilities by the bacterial symbiont of Paederus fuscipes beetles. J Bacteriol. 2004;186(5):1280-6.

49. Arrebola E, Cazorla FM, Codina JC, Gutierrez-Barranquero JA, Perez-Garcia A, de Vicente A. Contribution of mangotoxin to the virulence and epiphytic fitness of Pseudomonas syringae pv. syringae. Int Microbiol. 2009;12(2):87-95.

50. Carrion VJ, Arrebola E, Cazorla FM, Murillo J, de Vicente A. The mbo operon is specific and essential for biosynthesis of mangotoxin in Pseudomonas syringae. PLoS One. 2012;7(5), e36709.

51. Tamura K, Stecher G, Peterson D, Filipski A, Kumar S. MEGA6: molecular evolutionary genetics analysis version 6.0. Mol Biol Evol. 2013;30(12):2725-9.

52. Saitou N, Nei M. The neighbor-joining method: a new method for reconstructing phylogenetic trees. Mol Biol Evol. 1987;4(4):406-25.

53. Alikhan NF, Petty NK, Ben Zakour NL, Beatson SA. BLAST Ring Image Generator (BRIG): simple prokaryote genome comparisons. BMC Genomics. 2011;12:402.

54. Krzywinski M, Schein J, Birol I, Connors J, Gascoyne R, Horsman D, et al. Circos: an information aesthetic for comparative genomics. Genome Res. 2009;19(9):1639-45.

55. Field D, Garrity G, Gray T, Morrison N, Selengut J, Sterk P, et al. The minimum information about a genome sequence (MIGS) specification. Nat Biotechnol. 2008:26(5):541-7.

56. Woese CR, Kandler O, Wheelis ML. Towards a natural system of organisms: proposal for the domains Archaea, Bacteria, and Eucarya. Proc Natl Acad Sci U S A. 1990;87(12):4576-9.

57. Garrity GM, Bell JA, Lilburn T. Phylum XIV. Proteobacteria phyl. nov. In: Garrity GM, Brenner DJ, Krieg NR, Staley JT, editors. Bergey's Manual of Systematic Bacteriology, vol. 2. 2nd ed. New York: Springer; 2005. p. 2. part B:1.

58. Validation of publication of new names and new combinations previously effectively published outside the IJSEM. List no. 106. Int I Syst Evol Microbiol. 2005; 55:2235-2238.

59. Garrity GM, Bell JA, Lilburn T. Class III. Gammaproteobacteria class. nov. In: Garrity GM, Brenner DJ, Krieg NR, Staley JT, editors. Bergey's Manual of Systematic Bacteriology, vol. 2. 2nd ed. New York: Springer; 2005. p. 2. part B:1.

60. Orla-Jensen $\mathrm{S}$. The main lines of the natural bacterial system. J Bacteriol. 1921;6(3):263-73.

61. Winslow CEA, Broadhurst J, Buchanan RE, Krumwiede C, Rogers LA, Smith $\mathrm{GH}$. The families and genera of the bacteria: preliminary report of the committee of the society of american bacteriologists on characterization and classification of bacterial types. J Bacteriol. 1917;2(5):505-66.

62. Commission J. Opinion 5: Conservation of the generic name Migula 1894 and designation of aeruginosa (Schroeter) Migula 1900 as type species. Int Bull Bacteriol Nomencl Taxon. 1952;2:121-2.

63. Migula W. Über ein neues System der Bakterien. Arb Bakteriol Inst Karlsruhe. 1894; : $: 235-8$.

64. Anzai Y, Kim H, Park JY, Wakabayashi H, Oyaizu H. Phylogenetic affiliation of the pseudomonads based on 165 rRNA sequence. Int I Syst Evol Microbiol. 2000;50(Pt 4):1563-89. 
65. Bergey DH, Harrison FC, Breed RS, Hammer BW, Huntoon FM. Pseudomonas chlororaphis (Guignard and Sauvageau). In: Bergey et al., editors. Bergey's Manual of Determinative Bacteriology. 1930. p. 166.

66. Palleroni NJ. Pseudomonadaceae. In: Krieg NR, Holt JG, editors. Bergey's Manual of Systematic Bacteriology. Baltimore: The Williams and Wilkins Co; 1984. p. 141-99.

67. Ashburner M, Ball CA, Blake JA, Botstein D, Butler H, Cherry JM, et al. Gene ontology: tool for the unification of biology. The Gene Ontology

Consortium. Nat Genet. 2000;25(1):25-9.

\section{Submit your next manuscript to BioMed Central} and take full advantage of:

- Convenient online submission

- Thorough peer review

- No space constraints or color figure charges

- Immediate publication on acceptance

- Inclusion in PubMed, CAS, Scopus and Google Scholar

- Research which is freely available for redistribution 